\title{
Pengaruh Varietas dan Aplikasi Teknologi Budi Daya terhadap Kualitas Umbi Bawang Putih
}

\author{
EFFECT OF VARIETY DAN APPLICATION OF CULTIVATION TECHNOLOGY \\ ON GARLIC BULB QUALITY
}

\author{
Suwarni Tri Rahayu ${ }^{1 *}$, Rofik Sinung Basuki ${ }^{1}$, dan Poetry Sari Levianny ${ }^{1}$ \\ ${ }^{1}$ Balai Penelitian Tanaman Sayuran \\ Jln. Tangkuban Parahu No. 517, Lembang, Bandung Barat.

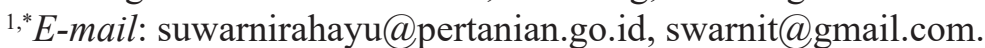

\begin{tabular}{ll}
\hline A R T I C L E I N F O & Abstract \\
\cline { 2 - 3 } Article history & Garlic demand in Indonesia currently still depends on import supply \\
Received date & due to its low production rate and quality which is still inadequate \\
25 January 2019 & to fulfill the consumers needs who want a greater supply of garlic. \\
Received in revised form date & Therefore, the government has been developing a technological \\
30 October 2019 & innovation for garlic cultivation, namely TIBBP, which is expected \\
Accepted date & to increase local garlic quality. This study aims to identify and \\
30 October 2019 & compare the influence of TIBBP method and conventional farming \\
Available online date & technology, and to compare the potential of garlic local varieties, \\
November 2020 & Lumbu Hijau and Tawangmangu Baru, on the parameter of garlic \\
& bulb quality. This research was conducted in Tawangmangu, \\
& Karanganyar, Central Java and designed by using a completely \\
& randomized design with three treatments and nine replications. The \\
& bulb quality was tested in Indonesian Vegetable Research Institute in \\
& Lembang. The result indicated that TIBBP method has been proven \\
& to increase garlic bulb quality compared to the farmer's conventional \\
& technology. Garlic bulb of Tawangmangu Baru cultivated by TIBBP \\
method showed an increase of 32.69\% in bulb diameter and 11.5 \\
gram in bulb weight as compared to Tawangmangu Baru cultivated \\
with the farmer's conventional technology. Tawangmangu Baru \\
proximate composition cultivated with TIBBP also showed better \\
value compared to the farmer's conventional technology. In general \\
Tawangmangu Baru was also superior compared to Lumbu Hijau. \\
This TIBBP might be disseminated and implemented broadly to \\
improve garlic bulb quality in Indonesia
\end{tabular}




\begin{tabular}{|c|c|}
\hline Kata kunci: & Abstrak \\
\hline $\begin{array}{l}\text { bawang putih } \\
\text { kualitas } \\
\text { budi daya } \\
\text { varietas lokal } \\
\text { lumbu hijau } \\
\text { Tawangmangu Baru }\end{array}$ & $\begin{array}{l}\text { Kebutuhan bawang putih di Indonesia saat ini masih tergantung } \\
\text { pasokan impor. Hal tersebut dikarenakan bawang putih lokal saat } \\
\text { ini belum mampu bersaing akibat rendahnya produksi dan kualitas } \\
\text { yang tidak sesuai dengan kebutuhan konsumen yang menginginkan } \\
\text { bawang putih berukuran lebih besar. Oleh karena itu, telah disintesis } \\
\text { paket teknologi inovatif budi daya bawang putih (TIBBP) yang } \\
\text { diharapkan mampu meningkatkan kualitas bawang putih lokal. } \\
\text { Penelitian ini dilakukan untuk mengetahui perbedaan pengaruh } \\
\text { paket TIBBP dan teknologi konvensional petani serta untuk melihat } \\
\text { perbedaan potensi varietas lokal, yaitu Lumbu Hijau dan Tawang- } \\
\text { mangu Baru terhadap kualitas umbi bawang putih. Lokasi penelitian } \\
\text { dilakukan di Tawangmangu, Karanganyar, Jawa Tengah. Penelitian } \\
\text { ini menggunakan Rancangan Acak Lengkap yang terdiri dari } 3 \\
\text { perlakuan dan } 9 \text { ulangan. Sementara itu, kualitas umbi diuji di Balai } \\
\text { Penelitian Tanaman Sayuran, Lembang. Hasil penelitian menun- } \\
\text { jukkan bahwa paket TIBBP terbukti mampu meningkatkan kualitas } \\
\text { umbi bawang putih dibandingkan teknologi konvensional petani. } \\
\text { Varietas Tawangmangu Baru yang dihasilkan dengan paket TIBBP } \\
\text { memiliki diameter umbi 32,69\% lebih besar dan bobot umbi } 11.5 \\
\text { gram lebih berat dibandingkan varietas yang sama dengan teknologi } \\
\text { konvensional petani. Kadar proksimat varietas Tawangmangu Baru } \\
\text { yang diolah dengan paket TIBBP juga lebih tinggi dibandingkan } \\
\text { teknologi konvensional petani. Varietas Tawangmangu Baru secara } \\
\text { keseluruhan juga lebih unggul dibandingkan varietas Lumbu Hijau } \\
\text { pada kondisi penanaman di lokasi penelitian. Paket TIBBP ini } \\
\text { diharapkan dapat didiseminasi dan diimplementasikan secara luas } \\
\text { sehingga dapat meningkatkan produktivitas, kualitas, dan daya saing } \\
\text { bawang putih lokal di Indonesia }\end{array}$ \\
\hline
\end{tabular}

C) 2020 Widyariset. All rights reserved

\section{PENDAHULUAN}

Bawang putih merupakan komoditas yang sangat penting untuk masyarakat Indonesia karena sering digunakan sebagai bumbu dalam masakan. Namun, untuk memenuhi kebutuhan saat ini Indonesia masih sangat bergantung kepada bawang putih impor. Produksi bawang putih di Indonesia pada tahun 2016 sebesar 21.150 ton (FAOSTAT 2018a), sedangkan besarnya impor mencapai 444.301 ton (FAOSTAT 2018b). Hal ini juga terlihat dari besarnya pengaruh harga bawang putih impor dan kebijakan penerapan tarif impor dan nilai tukar ru-piah terhadap ketersediaan dan konsumsi bawang putih di Indonesia (Wijaya 2014).

Konsumen juga lebih menyukai bawang putih impor dari Cina daripada bawang putih lokal karena harganya lebih murah dan umbinya lebih besar (Badan Penelitian dan Pengembangan Pertanian 2015). Ameriana (1998) mengemukakan bahwa bawang putih yang diminati konsumen adalah bawang putih yang ukurannya besar.

Varietas lokal bawang putih di Indonesia saat ini belum tersedia dalam jumlah yang banyak. Beberapa di antaranya adalah varietas Lumbu Hijau, Lumbu Kuning, Lumbu Putih, dan Tawangmangu Baru. Berdasarkan deskripsi varietas diketahui bahwa pada kondisi yang optimal keempat varietas ini dapat menghasilkan umbi dengan diameter berkisar antara 1,04-5,00 $\mathrm{cm}$. Namun, umumnya bawang putih lokal yang beredar di pasar berukuran lebih kecil 
dibandingkan ukuran optimum. Sementara itu, hasil karakterisasi dari 375 aksesi bawang putih asal Cina yang dilakukan Wang et al. (2014) mengemukakan bahwa rataan diameter umbi aksesi tersebut adalah sebesar 3,8 $\pm 0,67 \mathrm{~cm}$. Diameter terbesar dari aksesi tersebut bahkan mencapai 7,61 $\mathrm{cm}$.

Perbedaan ukuran diameter antara bawang putih lokal dan bawang putih asal Cina ini dapat terjadi karena berbagai macam faktor. Tyagi et al. (2017) mengemukakan bahwa jenis spesies dan varietas merupakan faktor utama dalam parameter kualitas, seperti warna, bentuk, ukuran, bobot beserta komposisi biokimia di dalamnya. Selain varietas, kondisi iklim juga dapat memengaruhi kualitas dari bawang putih. Bawang putih memerlukan suhu yang sejuk karena pada suhu di atas $32^{\circ} \mathrm{C}$ bawang putih akan berhenti tumbuh (Medina dan Gracia 2007). Selain itu, direkomendasikan saat penanaman sebaiknya dilaksanakan pada waktu musim gugur dengan suhu tanah pada kedalaman $10 \mathrm{~cm}$ adalah sebesar $10^{\circ} \mathrm{C}$ (Pam Dawling 2010). Kondisi ini sangat memungkinkan di Cina karena di daerah sentral penanaman bawang putih di Shandong, Cina, memiliki rataan suhu yang sejuk berkisar $-1-28^{\circ} \mathrm{C}$.

Kapasitas varietas di Indonesia mungkin tidak lebih unggul daripada dimiliki Cina dalam hal ukuran umbi. Selain itu, kondisi iklim di Indonesia juga tidak mendukung pertumbuhan bawang putih seperti di Cina. Namun, masih ada beberapa hal yang dapat dilakukan untuk meningkatkan kualitas umbi varietas lokal bawang putih Indonesia.

Teknologi budi daya merupakan salah satu hal yang dapat meningkatkan kualitas dan produktivitas dari komoditas. Berdasarkan hasil penelitian Diriba-Shiferaw et al. (2015), pemberian pupuk nitrogen, fosfor, dan sulfur secara signifikan memengaruhi ukuran diameter umbi bawang putih. Kombinasi dari ketiga pupuk tersebut dengan formulasi $138 \mathrm{~kg} \mathrm{~N} / \mathrm{ha}+$ $40 \mathrm{~kg} \mathrm{P} / \mathrm{ha}+30 \mathrm{~kg} \mathrm{~S} / \mathrm{ha}$ pada jenis tanah Andosol secara sinergis juga meningkatkan produksi bawang putih secara keseluruhan dan meningkatkan rataan diameter umbi dari 2,59 $\mathrm{cm}$ menjadi 4,98 cm. Tampaknya teknologi budi daya merupakan salah satu usaha yang menjanjikan dalam upaya peningkatan kualitas bawang putih.

Sebuah paket teknologi budi daya bawang putih saat ini tengah dikembangkan oleh Badan Litbang Pertanian sebagai upaya peningkatan produktivitas bawang putih. Paket teknologi budi daya ini disintesis berdasarkan temuan dari hasil penelitian sebelumnya. Hasil penelitian yang dijadikan acuan dalam perakitan paket teknologi ini meliputi teknologi pengoptimalan $\mathrm{pH}$ tanah menggunakan kapur dolomit (Hilman dan Suwandi 1992), penggunaan pupuk organik dan anorganik (Asandhi dan Gunadi 1985; Warjito et al. 1990; Suwandi dan Hilman 1991; Aliudin dan Asandhi 1992; Aliudin et al. 1992; Hilman 1994), penggunaan mulsa (Aliudin 1995), dan jarak tanam (Warjito et al. 1990).

Paket teknologi yang disusun berdasarkan hasil temuan tersebut disebutkenal sebagai Teknologi Inovatif Budi daya Bawang Putih (TIBBP). Fokus utama pengembangan TIBBP ini adalah untuk meningkatkan produktivitas bawang putih. Namun, faktor kualitas juga berperan sangat penting agar bawang putih lokal dapat bersaing dengan bawang putih impor. Informasi mengenai parameter kualitas umbi hasil dari TIBBP ini belum tersedia, maka dari itu penelitian ini dilakukan untuk mengetahui kualitas umbi hasil dari paket TIBBP ini.

Pengujian pengaruh dari aplikasi paket TIBBP terhadap kualitas umbi bawang putih dilakukan dengan membandingkan antara umbi hasil panen TIBBP dan 
teknologi konvensional yang biasa dilakukan oleh petani pada lokasi percobaan. Percobaan ini dilakukan di Tawangmangu, Karanganyar, Jawa Tengah pada musim penghujan. Ketinggian lokasi penelitian berada pada 1.080 meter di atas permukaan laut (mdpl). Berdasarkan ketinggian tersebut, varietas yang digunakan dalam penelitian ini adalah varietas Lumbu Hijau dan Tawangmangu Baru yang dapat tumbuh di dataran medium sampai tinggi. Selain itu, jika dibandingkan dengan varietas Lumbu Kuning yang juga dapat tumbuh di daerah ketinggian medium-tinggi, kedua varietas tersebut memiliki produktivitas yang lebih baik, yaitu 8-10 ton/ha dan 8-12 ton/ ha, secara berurut. Oleh karena itu, paket TIBBP menggunakan kedua varietas tersebut. Namun, pada teknologi konvensional, benih yang digunakan hanyalah dari varietas Tawangmangu Baru saja, sesuai dengan yang biasa digunakan oleh petani setempat. Setelah dipanen, dilanjutkan pengujian terhadap parameter-parameter kualitas umbi. Diharapkan melalui TIBBP ini kualitas bawang putih lokal dapat bersaing dengan bawang putih impor.

\section{METODOLOGI}

\section{Penanaman Bawang Putih}

Penanaman bawang putih dilaksanakan di Balai Benih Tanaman Pangan dan Hortikultura Karanganyar pada bulan Juli s.d. Desember 2017 di Tawangmangu, Karanganyar, Jawa Tengah.

Penelitian didesain dengan menggunakan perlakuan dari perbedaan teknologi budi daya bawang putih dan varietas benih yang digunakan. Jumlah perlakuan secara keseluruhan ada tiga. Perlakuan pertama adalah menggunakan teknologi budi daya konvensional yang biasa dilakukan oleh petani dengan menggunakan benih varietas Tawangmangu Baru. Perlakuan kedua dan ketiga adalah model budi daya dengan menggunakan paket TIBBP, yang berbeda hanyalah varietas yang digunakan. Pada perlakuan kedua varietas yang digunakan adalah Lumbu Hijau, sedangkan perlakuan ketiga yang digunakan adalah Tawangmangu Baru.

Perbedaan antara teknologi budi daya bawang putih konvensional dan paket TIBBP terletak pada sistem penanaman, pemupukan dasar dan susulan, teknik penanaman, serta penanggulangan hama dan penyakit.

\section{Teknologi Konvensional Petani}

Sistem penanaman bawang putih pada teknologi konvensional petani adalah sistem tumpang sari dengan komoditas bawang merah dan daun bawang. Varietas bawang putih yang digunakan dalam perlakuan ini adalah Tawangmangu Baru. Pada pengolahan tanah, dilakukan pemupukan awal, yaitu pemberian dolomit sebanyak 1,5 ton/ha. Kemudian pupuk dasar yang digunakan adalah pupuk kandang sapi sebanyak 40 ton/ha, SP 36 sebanyak $315 \mathrm{~kg} / \mathrm{ha}$, dan NPK 15.15 .15 sebanyak $315 \mathrm{~kg} / \mathrm{ha}$.

Pada saat penanaman, jarak tanam yang digunakan adalah 10x10 cm dengan menggunakan bedengan yang tidak ditutupi mulsa. Selanjutnya, pemupukan dilakukan sebanyak tiga kali selama masa tanam. Pada 20 HST diberikan 187,5 kg NPK 16.16.16/ha + 187,5 kg NPK 15.15.15/ha. Pada 40-50 HST diberikan $250 \mathrm{~kg}$ NPK 16.16.16/ha + $250 \mathrm{~kg} \mathrm{NPK} \mathrm{15.15.15/ha.}$ Terakhir, pada 70-75 HST diberikan 312,5 kg NPK 16.16.16/ha + 312,5 kg SP36/ha.

Penanggulangan hama dan penyakit pada teknologi konvensional petani dilakukan dengan menggunakan beragam jenis insektisida, yaitu Rampok, Regent, Abacel, Kanon, Curacron serta fungisida Score dan Dithane. Insektisida ini diberikan 2 kali dalam seminggu pada musim hujan atau 5 hari sekali pada musim kemarau. 


\section{Teknologi Inovasi Budi daya Bawang Putih (TIBBP)}

Penanaman bawang putih ini dilakukan dengan menerapkan sistem monokultur. Terdapat dua plot yang dibagi berdasarkan jenis varietas yang digunakan, yaitu Lumbu Hijau dan Tawangmangu Baru. Pada pemupukan awal dolomit yang digunakan adalah sebanyak 2 ton/ha. Pupuk dasar yang digunakan adalah pupuk kandang ayam sebanyak 25 ton/ha dan SP 36 sebanyak $375 \mathrm{~kg} / \mathrm{ha}$.

Jarak tanam yang digunakan adalah $10 \times 10 \mathrm{~cm}$ (sama seperti teknologi konvensional petani) dan bedengannya ditutupi mulsa jerami. Pemupukan susulan dilakukan sebanyak 4 kali, yaitu pada 21, 35, 49, dan 63 HST dengan dosis yang sama. Formulasi yang digunakan dalam pemupukan susulan adalah $286 \mathrm{~kg} \mathrm{Za} / \mathrm{ha}$ dan $50 \mathrm{~kg}$ $\mathrm{KCl} /$ ha.

Hama dan penyakit dikendalikan dengan mengggunakan insektisida Colicron dan Endure yang dipakai satu kali dalam seminggu. Selain itu, diberikan pula fungisida (Score, Daconil, dan Dithane) sebanyak dua kali dalam seminggu.

\section{Uji Kualitas}

Pengujian kualitas dilakukan di Laboratorium Fisiologi Hasil, Balai Penelitian Tanaman Sayuran pada bulan Desember 2017. Parameter mutu yang diamati adalah sifat fisik dan kadar proksimat umbi bawang putih pascapanen. Sifat fisik yang diamati adalah bobot kering umbi dan diameter umbi. Sementara itu, kadar proksimat yang dianalisis adalah kadar air, kadar abu, dan total padatan terlarut. Rancangan percobaan yang digunakan adalah Rancangan Acak Lengkap dengan 3 perlakuan dan 9 kali ulangan.

Bobot kering umbi diperoleh dengan menghitung bobot persatuan umbi bawang putih yang telah di-curing dan dikeringanginkan selama dua minggu, sedangkan diameter umbi diukur dengan menghitung diameter umbi pada bagian yang paling lebar secara horizontal. Pengujian kadar air dan kadar abu dilakukan dengan metode gravimetri, sedangkan nilai total padatan terlarut diukur menggunakan refraktometer.

Data dianalisis dengan menggunakan uji Anova dan apabila terdapat perbedaan yang nyata maka akan diuji lanjut menggunakan uji Least Significance Different (LSD) pada taraf 5\%. Aplikasi yang digunakan dalam mengolah data adalah Minitab 16.

\section{HASIL DAN PEMBAHASAN}

Parameter kualitas yang diamati pada penelitian ini adalah karakteristik fisik dan kadar proksimat umbi. Parameter kualitas ini dianggap sebagai parameter yang memengaruhi preferensi konsumen terhadap bawang putih.

\section{Karakteristik Fisik}

Parameter fisik yang diamati pada penelitian ini adalah bobot kering umbi dan diameter umbi. Berdasarkan hasil analisis statistik (Tabel 1), aplikasi teknologi budi daya bawang putih inovatif secara nyata memberikan hasil yang positif $(\mathrm{P}<0,05)$ terhadap parameter diameter ataupun bobot kering umbi bawang putih, baik menggunakan varietas Lumbu Hijau maupun Tawangmangu Baru. Diameter umbi Tawangmangu Baru yang dihasilkan melalui teknologi konvensional petani adalah sebesar $2,83 \mathrm{~cm}$, sedangkan dengan TIBBP menghasilkan umbi yang lebih besar, yaitu sebesar 3,84 $\mathrm{cm}$ atau 27,6\% lebih besar. Walaupun varietas yang digunakan sama, perbedaan diameter umbi hasil teknologi yang berbeda ini bisa mencapai \pm 1 $\mathrm{cm}$. Sementara itu, diameter umbi Tawangmangu Baru dan Lumbu Hijau dengan aplikasi TIBBP tidak memiliki perbedaan 
yang nyata. Hal ini menunjukan kedua varietas memiliki potensi yang sama baik.

Selain diameter, paket TIBBP juga memberikan hasil yang signifikan terhadap bobot kering umbi terlebih dengan menggunakan varietas Tawangmangu Baru. Perbedaan bobot umbi Tawangmangu Baru yang diolah dengan paket TIBBP mencapai 11,5 gram atau 203,9\% lebih berat dibandingkan bobot umbi varietas yang sama tetapi menggunakan teknologi budi daya konvensional petani. Sementara itu, umbi Tawangmangu Baru juga lebih unggul 6,99 gram dibandingkan Lumbu Hijau dengan teknologi budi daya yang sama. Hasil analisis data dapat dilihat pada Tabel 1.

Secara keseluruhan, hasil analisis karakteristik fisik umbi (Tabel 1) menunjukkan bahwa paket TIBBP secara signifikan meningkatkan kualitas fisik dari bawang putih, baik bobot maupun diameternya dibandingkan teknologi budi daya konvensional petani. Hal mendasar yang berbeda antara kedua teknologi adalah jenis pupuk yang diberikan. Pada pemupukan dasar, paket TIBBP menggunakan pupuk kandang ayam, sedangkan teknologi konvensional petani menggunakan pupuk kandang sapi. Pupuk kandang sapi sendiri mengandung banyak serat sehingga penyerapan unsur hara tersendat dan menekan pertumbuhan tanaman utama. Sebaliknya, pupuk kandang ayam memiliki kadar hara yang cukup dan relatif lebih mudah terdekomposisi dibanding dengan pupuk kandang lainnya (Hartatik dan Widowati 2006).

Selain pemupukan dasar, jenis pupuk susulan yang diberikan pada TIBBP dan teknologi konvensional petani juga berbeda. Teknologi konvensional petani menggunakan pupuk majemuk NPK 16:16:16 dan NPK 15:15:15 pada susulan pertama dan kedua, serta NPK 16:16:16 dan SP-36 pada susulan ketiga. Sementara itu, pada TIBBP, jenis pupuk yang diberikan pada susulan pertama hingga keempat adalah sama, yaitu menggunakan ZA dan $\mathrm{KCl}$. Pada pemupukan susulan ini terlihat bahwa pemberian nutrisi pada TIBBP lebih terfokus karena menggunakan pupuk tunggal dibandingkan pupuk majemuk yang digunakan pada teknologi konvensional petani. Hal ini menunjukkan bawang putih memberikan reaksi positif terhadap kombinasi ZA dan $\mathrm{KCl}$. Secara umum pemberian pupuk memang memberikan pengaruh terhadap kualitas dan atribut sensori suatu produk segar (Fallik dan Ilic 2018).

Tabel 1. Hasil analisis karakteristik fisik umbi

\begin{tabular}{lcc}
\hline Perlakuan & $\begin{array}{c}\text { Diameter } \\
(\mathbf{c m})\end{array}$ & $\begin{array}{c}\text { Bobot } \\
\text { Kering } \\
\text { (g) }\end{array}$ \\
\hline $\begin{array}{l}\text { Tek. Petani + } \\
\text { Tawangmangu } \\
\text { Baru }\end{array}$ & 2.83 a & 5.64 a \\
$\begin{array}{l}\text { TIBBP + Lumbu } \\
\text { Hijau }\end{array}$ & 3.61 b & 10.15 b \\
$\begin{array}{l}\text { TIBBP + } \\
\begin{array}{l}\text { Tawangmangu } \\
\text { Baru }\end{array}\end{array}$ & $17.14 \mathrm{c}$ \\
$\begin{array}{l}\text { Keterangan: Angka rata-rata yang diikuti huruf } \\
\text { yang sama pada kolom yang sama tidak berbeda } \\
\text { nyata (berdasarkan Uji LSD pada taraf 5\%) }\end{array}$
\end{tabular}

Bukan hanya pupuk, pemberian mulsa juga dapat memengaruhi kualitas umbi bawang putih. Material mulsa yang berbeda-beda juga memengaruhi secara berbeda pula. Jenis mulsa memang tidak memengaruhi atribut diameter umbi, tetapi memengaruhi tinggi tanaman, bobot umbi, bobot daun, dan produksi bawang putih (Bhuiya, Rahim, dan Chowdhury 2013). Bobot umbi terberat diperoleh ketika menggunakan mulsa eceng gondok seberat 12,78 gram, yang secara statistik juga tidak berbeda nyata dengan pemberian mulsa jerami seberat 12,53 gram, dan dibandingkan tanpa mulsa yang berat umbinya hanya 7,02 gram. Jamil et al. (2005) juga mengemukakan bahwa mulsa jerami dan mulsa plastik meningkatkan 
produksi umbi bawang putih, namun mulsa jerami lebih direkomendasikan karena secara keseluruhan performa yang dihasilkan lebih baik dan ekonomis serta merupakan bahan organik. Pemberian mulsa jerami pada paket TIBBP mungkin juga tidak berpengaruh terhadap diameter bawang putih, namun lebih berpengaruh terhadap peningkatan bobot umbi.

Salah satu hal yang paling berpengaruh terhadap produktivitas dan kualitas umbi adalah keunggulan dari varietas yang digunakan. Hal ini jelas terlihat dari hasil penelitian yang diperoleh, khususnya pada atribut bobot kering umbi. Varietas Tawangmangu Baru dan Lumbu Hijau yang ditanam dengan metode yang sama memiliki bobot yang berbeda secara signifikan, walaupun pada atribut diameter kedua varietas tidak menunjukan perbedaan yang signifikan. Produktivitas dan kualitas secara umum juga sangat dipengaruhi oleh varietas yang digunakan (Silabut 2014; Mirzaei, Liaghati, dan Damghani 2007).

Berdasarkan standar mutu yang dideskripsikan dalam SNI (Tabel 2), hasil umbi dari TIBBP, baik menggunakan varietas Lumbu Hijau maupun Tawangmangu Baru, keduanya menempati kelas I dalam aspek ukuran diameter, sedangkan hasil umbi teknologi konvensional petani menempati kelas II atau kelas mutu yang lebih rendah.

\section{Kadar Proksimat}

Kadar proksimat yang dianalisis pada penelitian ini adalah kadar air, kadar abu, Total Soluble Solid (TSS), dan kandungan sulfur. Melalui penelitian ini dapat diketahui bahwa umbi dengan kadar air tertinggi, yaitu sebesar $76,10 \%$ terdapat pada varietas Tawangmangu Baru yang diolah dengan tenologi konvensional petani. Sementara itu, pada varietas yang sama, Tawangmangu Baru, yang diolah dengan paket TIBBP memiliki kadar air yang paling rendah, yaitu $70,96 \%$.
Tabel 2. SNI 01-3160-1992 Standar Mutu Bawang Putih

\begin{tabular}{|c|c|c|}
\hline \multirow{2}{*}{ Karakteristik } & \multicolumn{2}{|c|}{ Syarat } \\
\hline & Mutu I & Mutu II \\
\hline Kesamaan sifat varietas & Seragam & Seragam \\
\hline Tingkat ketuaan & Tua & Tua \\
\hline Kekompakan siung & Kompak & $\begin{array}{l}\text { Kurang } \\
\text { kompak }\end{array}$ \\
\hline Kebernasan siung & Bernas & $\begin{array}{l}\text { Kurang } \\
\text { bernas }\end{array}$ \\
\hline \multirow[t]{2}{*}{ Kekeringan } & Kering & Kering \\
\hline & Simpan & Simpan \\
\hline $\begin{array}{l}\text { Kulit luar pembungkus } \\
\text { umbi }\end{array}$ & $\begin{array}{l}\text { Sempurna } \\
\text { menutup } \\
\text { umbi }\end{array}$ & $\begin{array}{l}\text { K u ra n g } \\
\text { sempurna } \\
\text { menutup } \\
\text { umbi }\end{array}$ \\
\hline $\begin{array}{l}\text { Kerusakan, } \\
\%(\text { bobot-bobot) maks. }\end{array}$ & 5 & 8 \\
\hline $\begin{array}{l}\text { Busuk, } \\
\% \text { (bobot/bobot) maks. }\end{array}$ & 1 & 2 \\
\hline $\begin{array}{l}\text { Diameter minimum, } \\
\text { cm. }\end{array}$ & 3,0 & 2,5 \\
\hline Kotoran & Tidak ada & Tidak ada \\
\hline
\end{tabular}

Air merupakan komposisi utama pada tanaman pangan yang mengikat komposisi lainnya dengan daya fisik dan kimia dari kondisi dan kekuatan alam (Edeougu et al. 2007). Namun, kadar air yang lebih tinggi memengaruhi daya simpan yang dimiliki oleh produk karena kandungan air yang tinggi dapat menjadi tempat bersarangnya mikroba. Maka dari itu, terlihat bahwa kadar air varietas Tawangmangu Baru yang diolah dengan paket TIBBP berpotensi memiliki daya simpan yang lebih tinggi dibandingkan yang diolah dengan paket teknologi konvensional petani.

Melalui teknologi budi daya yang sama yaitu dengan paket TIBBP, varietas Tawangmangu Baru dan Lumbu Hijau memiliki kadar air yang berbeda. Kadar air umbi varietas Tawangmangu Baru yang ditanam dengan menggunakan metode TIBBP memiliki kadar air yang paling rendah dibandingkan kedua perlakuan lainnya, yaitu 70,96\%. Hal ini menunjukkan bahwa perlakuan tersebut memiliki potensi 
daya simpan yang lebih tinggi. Hasil analisis data dapat dilihat pada Tabel 3 .

Kadar air dari ketiga perlakuan ini cenderung lebih tinggi dibandingkan kadar air dari bawang putih yang diteliti oleh Sajid et al. (2014), di mana kadar air rataan yang diperoleh adalah $64,58 \pm 2,06 \%$. Hal ini dapat terjadi karena perbedaan varietas, kondisi alam, dan pemberian pupuk yang berbeda. Tyagi et al. (2017) mengemukakan bahwa spesies dan varietas merupakan faktor utama yang memengaruhi perbedaan parameter kualitas, seperti warna, bentuk, ukuran, bobot, dan sifat bio-kimia.

Tabel 3. Hasil uji kadar proksimat umbi bawang putih

\begin{tabular}{lccc}
\hline Perlakuan & $\begin{array}{c}\text { Kadar air } \\
\text { (\%) }\end{array}$ & $\begin{array}{c}\text { Kadar abu } \\
\text { (\%) }\end{array}$ & $\begin{array}{c}\text { TSS } \\
\text { ('Brix) }\end{array}$ \\
\hline $\begin{array}{l}\text { Tek. Petani }+ \\
\text { Tawangmangu } \\
\text { Baru }\end{array}$ & 76,10 & 1,20 & 23,47 \\
$\begin{array}{l}\text { TIBBP + Lumbu } \\
\text { Hijau }\end{array}$ & 74,46 & 1,13 & 24,87 \\
$\begin{array}{l}\text { TIBBP + } \\
\text { Tawangmangu } \\
\text { Baru }\end{array}$ & 70,96 & 1,68 & 28,60 \\
\hline
\end{tabular}

Kadar abu merupakan salah satu parameter yang diuji untuk mendapatkan gambaran mengenai jumlah elemen mineral yang ada dalam suatu sampel makanan (Edeougu et al. 2007). Pada penelitian ini, varietas Tawangmangu Baru yang diolah menggunakan paket TIBBP menghasilkan nilai kadar abu tertinggi, yaitu sebesar $1,68 \%$ dibandingkan varietas Tawangmangu Baru yang diolah secara konvensional dengan kadar abu sebesar 1,20\%. Selisih yang cukup besar ini menandakan bahwa ada kemungkinan pemberian pupuk dapat memengaruhi kadar abu pada bawang putih.

Berbeda dengan varietas Lumbu Hijau yang diolah dengan paket TIBBP, nilai kadar abu yang dimiliki merupakan nilai terendah dibandingkan semua perlakuan yang diberikan, yaitu sebesar $1,13 \%$. Hal ini juga menunjukkan bahwa varietas Tawangmangu Baru memiliki kadar abu yang lebih tinggi dibandingkan varietas Lumbu Hijau.

Walaupun demikian, nilai kadar abu pada ketiga perlakuan masih lebih kecil dibandingkan dengan kadar abu bawang putih pada penelitian Sajid et al. (2014). Kadar air bawang putih yang diuji memiliki nilai rataan 2,46 $\pm 0,09 \%$. Sementara itu, penelitian Gadel-Hak et al. (2015) terhadap enam genotipe bawang putih menunjukkan kadar abu yang bervariasi antara $1.73 \%-$ $2.75 \%$. Kadar abu terendah terdapat pada genotipe 'Sids-40' dan yang tertinggi adalah 'Egassed-1'. Dalam penelitiannya, dikemukakan bahwa terdapat perbedaan komposisi organosulfur, komposisi padatan, kepedasan dan aktivitas antiplatelet bervariasi antara klon bawang putih yang berada pada kelompok ekofisiologi yang berbeda dan varietas yang berbeda namun dalam satu kelompok ekofisiologi yang sama.

Kadar proksimat lainnya yang dianalisis adalah Total Soluble Solid (TSS) atau total padatan terlarut. Menurut Gonzalez et al. (2009), total padatan terlarut merupakan atribut kualitas umbi yang penting terkait tahapan proses dan penyimpanan. Hasil penelitian ini menunjukkan bahwa varietas Tawangmangu Baru yang diolah dengan paket TIBBP memiliki nilai TSS tertinggi, yaitu sebesar $28,60^{\circ}$ Brix. Apabila dibanding dengan varietas yang sama, namun diolah dengan teknologi konvensional petani, nilai TSS menjadi lebih rendah, yaitu sebesar $23,47 \%$ dan merupakan nilai TSS terendah dari ketiga perlakuan yang diberikan.

Tidak jauh berbeda dengan varietas Tawangmangu Baru yang diolah secara konvensional, varietas Lumbu Hijau yang diolah dengan paket TIBBP memiliki nilai TSS sebesar $24,87^{\circ}$ Brix. Apabila dibanding dengan varietas Tawangmangu Baru 
yang diberi perlakuan sama, terlihat bahwa varietas Tawangmangu Baru lebih unggul dibandingkan varietas Lumbu Hijau.

Secara keseluruhan nilai dari ketiga sampel juga masih lebih rendah dibandingkan nilai TSS bawang putih yang diteliti oleh Gonzales et al. (2009), di manadengan nilai TSS bervariasi antara 29,22-39, $3^{\circ}$ Brix. Menurut DiribaShiferaw et al. (2014), terdapat pengaruh dari integrasi pemberian nitrogen, fosfor, dan sulfur terhadap kualitas umbi bawang putih. Pemberian nitrogen, sulfur, interaksi antara fosfor dan sulfur, serta interaksi antara nitrogen, fosfor, dan sulfur memengaruhi nilai TSS. Selain itu, nilai TSS juga dipengaruhi oleh jenis tanah yang berbeda.

Melalui penelitian terhadap ketiga parameter proksimat yang telah diuji, varietas Tawangmangu Baru yang diolah dengan paket TIBBP menunjukkan keunggulan terhadap semua parameter yang diuji.

Secara keseluruhan, baik dari aspek kualitas fisik maupun proksimat, paket TIBBP lebih unggul dibandingkan paket konvensional petani karena mampu meningkatkan kualitas umbi bawang putih. Selain itu, varietas Tawangmangu Baru juga lebih unggul dibandingkan Lumbu Hijau berdasarkan parameter-parameter yang diuji.

\section{KESIMPULAN}

Paket TIBBP terbukti mampu meningkatkan, baik kualitas fisik maupun kadar proksimat dari umbi bawang putih dibandingkan teknologi konvensional petani. Varietas Tawangmangu Baru yang dihasilkan dengan paket TIBBP memiliki diameter 32,69\% lebih besar dan bobot 11,.5 gram lebih berat dibandingkan varietas yang sama dengan teknologi konvensional petani. Apabila dibandingkan Lumbu
Hijau, varietas Tawangmangu Baru juga memiliki nilai kualitas yang lebih unggul walaupun ditanam dengan teknologi budi daya yang sama.

\section{SARAN/REKOMENDASI}

Paket TIBBP ini diharapkan dapat dijadikan acuan dalam pembuatan Good Agricultural Practice (GAP) bawang putih.

\section{UCAPAN TERIMA KASIH}

Penulis mengucapkan terima kasih kepada Kepala Balai dan Kepala Kebun Balai Benih Tanaman Pangan dan Hortikultura Karanganyar yang telah membantu kelancaran penelitian ini. Ucapan terima kasih juga penulis sampaikan kepada para teknisi dan litkayasa yang terlibat, yaitu Nana Sukmana, Udin Syamsudin, Mamat Rachmat, Enung Murtiningsih, Asep P., dan Fahmi H.

\section{DAFTAR ACUAN}

Aliudin, dan A.A Asandhi. "Respons Tiga Kultivar Bawang Putih Dataran Rendah terhadap Dosis Pupuk Kandang di Dataran Tinggi”. Bull Penel Hort. 24, No. 2(1992): 11-18

Aliudin, A.N., dan Yuliarin, M. Tampubolon. "Frekuensi Pemberian Pupuk Nitrogen (ZA) pada 2 Kultivar Tanaman Bawang Putih". Bull. Penel. Hort. 22(1992): 65-72.

Aliudin. "Pengaruh Pemulsaan dan Pemberian Herbisida terhadap Hasil Panen Bawang Putih". Bull. Penel. Hort. 27(1994): 55-60.

Aliudin. "Pengaruh Cara Pengendalian Gulma pada Keadaan Bermulsa dan Tidak Bermulsa terhadap Pertumbuhan Hasil Panen Bawang Putih". Bull. Penel. Hort. 27(1995): 23-30. 
Ameriana, M. "Perbaikan Kualitas Sayuran Berdasarkan Preferensi Konsumen". Monograf . 17(1998): 1-20.

Asandhi, A.A., dan N. Gunadi. "Pengaruh Pemupukan Nitrogen terhadap Pertumbuhan dan Hasil Bawang Putih di Musim Hujan”. Bull. Penel. Hort. 12(1985): 5-10.

Badan Penelitian dan Pengembangan Pertanian. Pendekatan Dinamika Sistem dalam Peningkatan Daya Saing Komoditas Hortikultura. Diedit oleh Tjeppy D. Soedjana, Rita Nurmalina, Uning Budihanti, dan Dyah Widyastuti. Bogor: IAARD Press, 2015.

Bhuiya, M.A.K, M.A. Rahim, dan M.N.A Chowdhury. "Effect of Planting Time, Mulch, and Irrigation on the Growth and Yield of Garlic". Asian Journal of Plant Sciences. 2 No. 8(2003): 639-643. https://scialert. net/abstract/?doi=ajps.2003.639.643

Edeougu, C.O., F.C. Ezeonu, A.N.C Okaka, C.E Ekuma, dan S.O Elom. "Proximate Compositions of Staple Food Crops in Ebonyi State, South Eastern Nigeria". Interantional Journal of Biotechnology and Biochemistry 3(2007): 57--67. https://www.researchgate.net/ publication/.

De La Cruz, and H. S. Gracia. "Garlic: Post- Harvest Operatio." Agricultural and Food Engineering Technologies Service. 2007, 2-40. http://www.fao. org/fileadmin/user_upload/inpho/ docs/Post_Harvest_Compendium_--

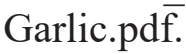

Diriba-Shiferaw, G., R. Nigussie-Dechassa, K. Woldetsadik, G. Tabor, dan J.J. Sharma. "Bulb Quality of Garlic (Allium sativum L .) as Influenced by the Application for Inorganic Fertilizers". African Journal of Agricultural Research.9No. 8(2014): 778-90. https://academicjournals. org/journal/AJAR/.
Diriba-Shiferaw, G., R. NigussieDechassa, K. Woldetsadik, G. Tabor, dan J.J Sharma. "Effect of Nitrogen, Phosphorus, and Economic Returns of Garlic (Sulphur Fertilizers on Growth, Yield, and Economic Retuns of Garlic (Allium sativum L.)". Sci. Technol. Aets Res. J. 4 No. 2(2015): 10-22. http://www.starjournal.org/.

Fallik, E., dan Z. Ilic. "Pre- and Postharvest Treatments Affecting Flavor Quality of Fruits dan Vegetables". Dalam Preharvest Modulation of Postharvest Fruit and Vegetable Quality. Diedit oleh Mohammed Wasim Siddiqui. Academic Press, 2018.

FAOSTAT. "Production Crops Asia". 2018a. http://fenixservices.fao. org/faostat/static/bulkdownloads/ Production_Crops_E_Asia.zip. . "Trade Crops Livestock Asia". 2018b. http://fenixservices.fao. org/faostat/static/bulkdownloads/ Trade_Crops_Livestock_E_Asia.zip

Gadel-Hak, S. N. H., Y. M. M. Moustafa, G. F. Abdel-Naem, and I. A. Abdel-Wahab. "Studying Different Quantitative and Qualitative Traits of Some White-and Colored-Bulb Garlic Genotypes Grown under a Drip Irrigation System." Australian Journal of Basic and Applied Sciences 5, no. 6 (2011): 1.415-1.427.

Gonzalez, R. Elizabeth, V. C. Soto, M. M. Sance, A.B. Camargo, dan C.R. Galmarini. "Variability of Solids, Organosulfur Compounds, Pungency and Health-Enhancing Traits in Garlic (Allium sativum L.) Cultivars belonging to Different Ecophysiological Groups". J. Agric. Food Chem. 57 No. 21(2009): 10.282-10.288. https://pubs.acs.org/ doi/10.1021/jf9018189 
Hartatik, W., dan L. R. Widowati. 2006. "Pupuk Kandang”. Dalam Pupuk Organik dan Pupuk Hayati (Organic Fertilizer and Biofertilizer). Bogor: Balai Besar Penelitian dan Pengembangan Sumberdaya Lahan Pertanian, 2006. http://repository.pertanian.go.id/ bitstream/handle/123456789/9394/ $\mathrm{P} \mathrm{u} \mathrm{p} \mathrm{u} \mathrm{k \%} 20 \mathrm{Organik \% 20}$ d a n \% $20 \mathrm{Pupuk} \% 20 \mathrm{Hay}$ at i . pdf? sequence $=1 \&$ isAllowed $=\mathrm{y}$.

Hilman, Y., dan Suwandi. "Cara Pemberian Tembaga dengan Dosis dan Sumber Pupuk Kalium, Magnesium dan Kalsium pada Bawang Putih". Bull. Penel. Hort. 23, No. 4(1992): 85-96.

Hilman, Y. "Pengaruh Cara Aplikasi Phosohat dan Kombinasi Pupuk Nitrogen, Phosphat dan Kalium terhadap Pertumbuhan dann Hasil Bawang Putih yang Ditanam dengan Sistem Cemplongan". Bull. Penel. Hort. 26, No.3 (1994): 1-10.

Jamil, M. M. Munir, M. Qasim, Jalaluddin Baloch, dan K Rehman. "Effect of Different Types of Mulches and Their Duration on the Growth and Yield of Garlic (Allium sativum L.)." International Journal of Agriculture \& Biology 7, No. 4 (2005): 588-91.

Mirzaei , R, H Liaghati, dan A Mahdavi Damghani. "Evaluating Yield Quality and Quantity of Garlic as Affected by Different Farming System and Garlic Clones." Pakistan Journal of Biological Science 10, No. 13 (2007): 2219-24.

Pam Dawling. "How and When to Plant Garlic." Growing for Market. 2010. https://www.growingformarket.com/ articles/how-and-when-to-plantgarlic.

Silabut, Neeraj, I. S. Naruka, R. P. S. Shaktawat, K. S. Verma, and Azeze Seyie. "Response of garlic cultivars to irrigation levels." Indian Journal of Horticulture 71, No. 3 (2014): 354-359.
Sajid, Marina, Masood Sadiq Butt, Aamir Shehzad, dan Saira Tanweer. "Chemical and Mineral Analysis of Garlic: A Golden Herb." Pakistan Journal of Food Sciences 24, No. 1 (2014): 108-10. https://doi. org/10.1093/annonc/mds294.

Suwandi dan Y. Hilman. "Pengaruh Sumber dan Dosis Pemupukan Fosfat pada Tanaman Bawang Putih Kultivar Lumbu Hijau". Bull. Penel. Hort. 21, No. 1 (1991): 108-118.

Tyagi, Sachin, Sanjay Sahay, Mohd. Imran, Kumari Rashmi, dan Shiv Mahesh. "Pre-Harvest Factors Influencing the Postharvest Quality of Fruits: A Review." Current Journal of Applied Science and Technology 23 No. 4(2017): 1-12. https://doi. org/10.9734/cjast/2017/32909

Warjito, A. Zaenal dan S.M. Rachmat. "Pengaruh Pemberian Pupuk Kandang Sapi dan Kerapatan Populasi terhadap Pertumbuhan dan Hasil Bawang Putih Kultivar Lumbu Hijau". Bull. Penel. Hort. 19, No. 3(1990): 29-37.

Wang, Haiping, Xixiang Li, Di Shen, Yang Oiu, dan Jiangping Song. "Diversity Evaluation of Morphological Traits and Allicin Content in Garlic (Allium sativum L.) from China." Euphytica 198 No. 2(2014): 243-54. https://doi.org/10.1007/s10681-0141097-1.

Wijaya , I Putu Eka. “Analisis Konsumsi dan Ketersediaan Bawang Putih di Indonesia." Yogyakarta: Universitas Gadjah Mada, 2014. [Online]. http:// etd.repository.ugm.ac.id/index.php?$\bmod =$ penelitian detail\&sub=PenelitianDetail\&act=view\&typ=html\&buku_id $=69274 \&$ is_local $=1$. 